\author{
大木 達也 ${ }^{1 *}$ ・古屋仲 茂樹 ${ }^{1} \cdot$ 西須 $^{\text {佳宏 }}{ }^{1} \cdot$ 林 直人 ${ }^{1}$
}

\title{
Advanced Physical Separation Technology for Rare Metal Recycling
}

\author{
Tatsuya OKI ${ }^{1}$, Shigeki KOYANAKA ${ }^{1}$, Yoshihiro NISHISU ${ }^{1}$ and Naohito HAYASHI ${ }^{1}$
}

\author{
${ }^{1}$ Advanced Recycling Technology Group, Research Institute for Environment Management, \\ National Institute of Advanced Industrial Science and Technology (AIST), Tsukuba 305-8569, Japan
}

\begin{abstract}
Physical separation is a technology to produce valuable metal powder from metals included in waste products. Many separation technologies are already used in conventional recycling processes for the recovery of common and precious metals. However, there are few separation technologies for the recovery of expensive metals such as tantalum and rare earth metals, which are called "rare-metals" in Japan, from small domestic appliances (SDAs). Advanced grinding, sorting and separation techniques have been investigated in our research group in order to recycle these metals from SDAs. Our representative studies for advanced physical separation processes are introduced, and the future picture of physical separation which we have painted is described in this report.
\end{abstract}

Key words: Recycling, Physical separation, Rare-metals, Grinding, Sorting

\section{1. 緒言}

国内に広く分散して存在する廃製品等から希少金属を 回収する所謂「都市鉱山」の開発に扣いては, これらを 合理的に収集できる社会基盤整備が, 資源化への第一歩 となる。これについては，すでに経済産業省や環境省が モデル地域に対して収集実験を行って抢り，種々，克服 すべき課題はあるものの, システム構築に向けて着実に 前進している1。一方，廃製品等の継続的な大規模収集が 実現したとしても，これらに含まれる全ての金属が資源 化できるわけではない。既に中間処理一製錬技術が確立 されている鉄, アルミ，銅，貴金属など，大規模かつ組 織的な再資源化が可能な金属は, 種類としてはごく限ら れている。特に多くの希少金属は廃製品中に低濃度でし か含まれず，そのまま湿式製錬工程で回収することは経 済的に難しい。また，低濃度の貴金属を効率的に回収で きる銅製錬工程でも，希少金属はスラグ側に配分される ものが多く，その回収は技術的に困難となる。

このような廃製品中に含有するより多くの希少金属に 対して, 資源価値を付与する 1 つの方法が物理選別によ

キーワード：リサイクル, 物理選別, レアメタル, 粉砕, ソーティング

1 産業技術総合研究所環境管理技術研究部門リサイクル 基盤技術研究グループ

平成 23 年 6 月 21 日受理

*e-mail: t-oki@aist.go.jp
る金属の 1 次濃縮である。廃製品から資源を回収する際 に最初に施されるプロセスであり，製錬の前処理工程で あるので中間処理とも呼ばれる。廃製品を解体, 粉砕, 選別する工程からなるが, 多種多様な製品から精度良く 金属を回收するために，我が国に拈いても，未だ多くの 工程で手作業が多用されているのが実状である。しかし, 希少金属を対象とした場合には，それが微小な部品で あったり，製品中に極少量しか利用されていなかったり など，手作業による回収が著しく非効率であることが少 なくない。また，国際競争力を維持した再資源化を目指 すには，廃製品から希少金属を大量かつ低コストに回収 するため, 選別プロセスの機械化，あるいは既存機の最 適化，高度化を図ることが不可欠となってくる。

これらの問題を解決するため, 筆者らは, 固体粒子の 粉砕, 選別, 認識技術を駆使した物理選別の要素技術や, 各種廃製品に特化した物理選別技術の開発を行ってい る。本稿では, その社会的ニーズと, 筆者らが開発して いる代表的な物理選別技術の概要について紹介すると共 に, 我々が目指寸物理選別技術の将来像とその役割につ いて付記した。

\section{2. 手選代替個別破砕・選別技術}

\section{1 製品の資源価値評価}

従来の中間処理工程に打いては, 廃製品を一緒くたに 粉砕し, 比重や磁性などの物性の差に基づいて, 鉄やア 


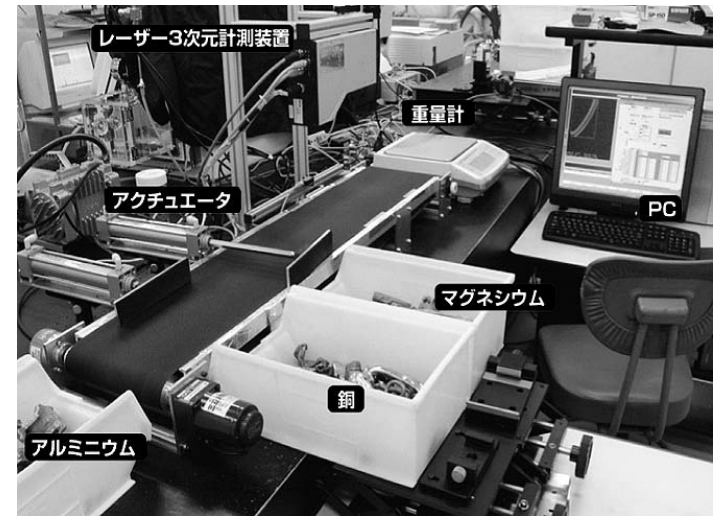

Fig. 1 3D-lazer sensing system

ルミなど一部の金属を回収していた。しかし，このよう なベースメタルを回収する方法では，含有率の低い特定 の希少金属のみを回収することは不可能に近い。また， 廃製品中に含有する希少金属の量は，製品により様々で ある。例えば，携帯電話あるいはデジタルカメラといっ た同一種類の製品に限定したとしても，製造年代やメー カー，機種などにより，希少金属の構成は千差万別であ る。ここで，物理選別工程に投入する前に，予め特定の 希少金属を多く含む製品だけを集めることができれば, その後, より高精度な選別ができる可能性も生まれる。 例えば, 製品中の希少金属元素含有量を記録した IC チッ プを製品に貼付すれば，センサーでこれを読み込むこと で，将来的には希少金属濃度別に製品を予備選別するこ とも可能となろう。しかし，全ての製品にこの方式が普 及し，かつ，これらが廃製品として中間処理されるまで には, 10 年から 20 年以上の月日が必要となる。

それまでの間，これに類するシステムを導入するため の技術開発として，筆者らは，安価なセンシング技術を 駆使した廃製品の総合的資源価值判断システムを検討し ている。アルミやマグネシウムの選別で実績のある 3 次 元レーザーセンシング (Fig. 1 参照) により, いくつか の製品について，3 次元形状，体積，重量など，安価に 計測可能な物性情報を取得している象。ニューラルネッ トワークを駆使して，これらの物性情報と予め取得した 製品の資源価值情報を照合しながら，製品及びその資源 価值の判別を行らものである。この方法では，前述の IC チップ貼付に比べ，選別の不確実さや製品情報の網羅性 などが懸念されるが，比較的高品位の製品を予め抜き出 すのに，必ずしも $100 \%$ の選別精度は必要でなく，また， 製品情報の整った特定の製品だけに限って実施したとし ても一定の効果を期待することができる。現在，携帯電 話など特定の製品について，部品レベルでの資源的価值 を瞬時に判定，どのような物理選別工程が相応しいのか

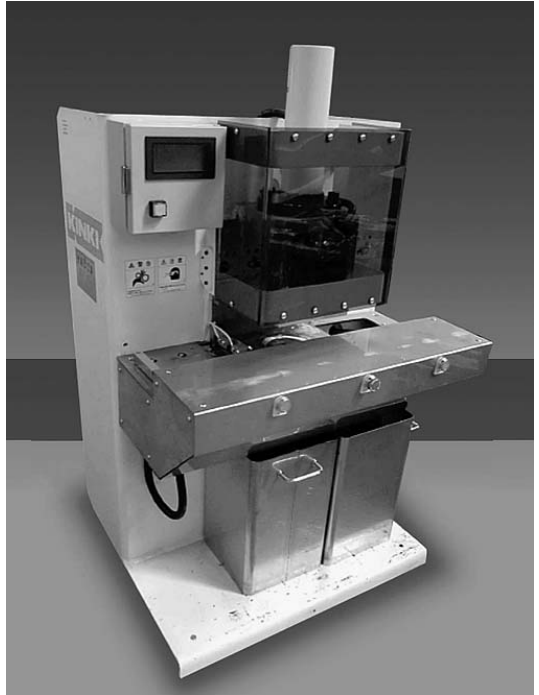

Fig. 2 HDD cutting separator

を総合的に判断して，これらを自動選別するシステムの 実現を目指している。

\section{2 個別破砕 - 選別技術}

製品を機械的に破砕する前に，破砕に適さない硬い部 品や強力な磁石，あるいは破砕により価值が低下寸る部 品などは, 予め手解体, 手選別により回収することが望 ましい。しかしながら, 我が国に拈いて, 手解体, 手選 別を多用することは, 大量処理を困難にするだけでなく， 再生資源の国際競争力を失ら結果にもなりかねない。そ の機械化を目指して検討を進めているのが，個別破砕技 術である。これは，手解体の代替として，機械が対象物 を 1 つ 1 認識しながら破砕を行ら, 筆者らが開発中の 技術である。

現在，その手始めとして，ハードディスクドライブ （HDD）用の磁石抜き取り装置, HDD カッティングセパ レータ（HDD-CS）を近畿工業株式会社と共同で開発中 である (Fig. 2 参照) ${ }^{4-6}$ 。 HDD のボイスコイルモータに は，ネオジムやジスプロシウムなどのレアアースを含む ネオジム磁石が使用されて扣り，その回収の期待が高 まっている。しかし，HDDを通常の破砕機に投入して集 合破砕すると，ネオジム磁石が鉄スクラップとして回収 されてしまらばかりでなく，その強力な磁力によって破 砕機内に強固に磁着し, スクリーンの閉塞などトラブル の原因にもなる。また，運よく破砕機から排出されても， 他の鉄片などと強固に磁着し高度な濃縮を達成すること ができない。

その 1 つの解決法が, 事前に脱磁することである。ネ オジム磁石はキュリ一点が比較的低いため, $300^{\circ} \mathrm{C}$ 程度 に加熱すれば概水磁力が失われる。しかし，重量割合で 
わずか 2 ～3\%しか含まれない磁石を脱磁するのに, HDD 全体を加熱するのは効率が悪い。強力な磁場に置いて非 加熱脱磁する方法も有力な手段であるが, 装置が高価で あるなど汎用性に課題がある。このような背景から，現 状では手作業による解体が現実的な回収方法であるが, 経済性や生産性に富む実用的な機械化技術が求められて いた。

HDD-CS では, 2 個の位置センサーと 4 個の磁気セン サーを配し, HDD の表面に漏洩する磁気をセンシングす ることで, ネオジム磁石を含有するボイスコイルモータ （VCM）の位置を非破壊で瞬時に特定することができる。 その後, VCM 部を非磁性鋼製の刃の直下に搬送し, VCM 部のみを打ち抜くことにより，HDDを脱磁せずに，ネオ ジム磁石を 10 倍程度に濃縮することが可能である。処理 時間は 1 台あたり 15 ～ 20 秒程度で，打ち抜かれたネオ ジム磁石部以外, HDD は, ほぼ無傷で回収できることも 特徵の 1 つである。1/10の量に濃縮された磁石部は, 脱 磁処理をしたのち, 現在開発中の選択粉砕プロセスによ り, ラボスケールに扣いて, 純度 $94 \sim 97 \%$ 程度の脱磁 されたネオジム磁石合金粉末を回収することに成功して いる。

HDD-CS は, 現在, 3.5 インチ HDD 専用機を試作した段 階である。しかし，廃製品中の見えない部位をセンシン グにより検知し，ピンポイントで切り抜く技術は，様々 な対象物に対して適用が可能であり, 今後, 希少金属り サイクルの可能性を広げる重要な技術の1つとして発展 することが期待される。

\section{3. 集合破砕・選別技術}

\section{1 選択粉砕技術}

使用済久製品から適当な部品レベルに選別されたもの や，優先的に部品が取り出されたあとの製品は，集合粉 砕 (従来の粉砕) 工程に送られる。この工程では, 単に, 粒子を目的のサイズにするためだけでなく, 着目金属の 単体分離（1 粒子が 1 成分からなる状態）を促進させる ことが重要な目的となる7。物理選別は, 粒子を選り分け る操作であるから，粒子が単体分離していなければ，高 度な選別は達成されない。例えば, 回収対象の着目粒子 がある 1 種の金属元素である場合には，1 粒子がその金 属元素から構成される状態を単体分離した状態と呼ぶ。 また，着目粒子が特定の合金であれば 1 粒子が 1 種の合 金からなる状態を，着目粒子が部品など特定の複合体な らば，それが 1 粒子として構成されていれば同様に単体 分離したと扱ってよい。廃製品は人工物ゆえ, 着目成分 が複合体中で特定のドメインサイズを有していることが 多い。また, 破壊特性が極端に異なる物と隣り合って配

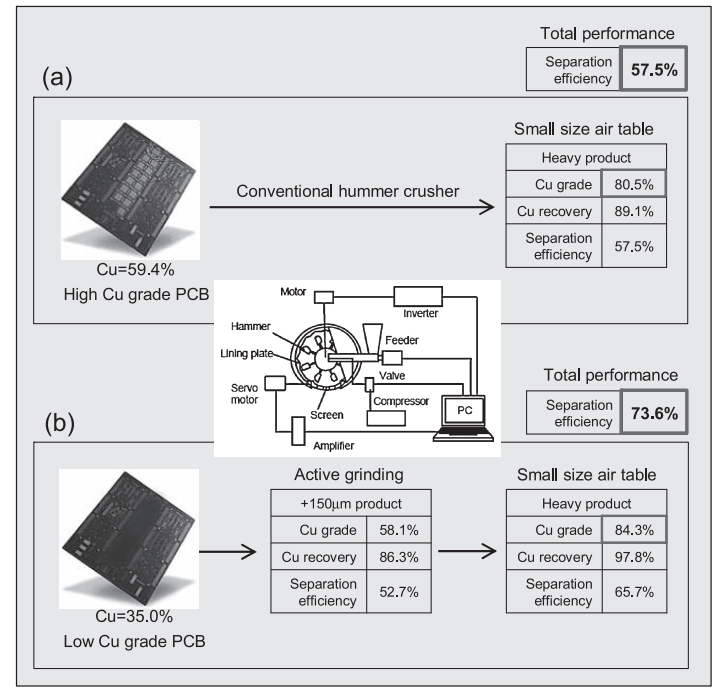

Fig. 3 Separation results using an active grinding

置されることも少なくなく, 製品によっては天然鉱石に 比べても, 単体分離させやすい場合がある8。しかしなが ら,これまで, 単体分離の促進を主目的に開発された破 砕機はほとんどなく, 現状に打いては, 廃製品と既存粉 砕機の膨大な組又合わせを検証して, 偶然, 特定の製品 の単体分離に適した破砕機を見出す他に方法はない。

そこで筆者らは, 単体分離の促進を主目的とした破砕 技術の開発を手がけている。アクティブ粉砕（Fig. 3 参 照）は, ハンマクラッシャの実時間的運転制御により, 特定の素材を優先的に破壊したり，異相境界面での破壊 を促進させる選択粉砕技術である ${ }^{9,10}$ 。試料を連続バッチ 式に投入し，ハンマの回転速度やスクリーンの開口の度 合いを実時間的に制御し, 最適化する。これにより, 破 砕初期に異相境界面にクラックを発生させ, その後, ク ラックなどの脆弱部に応力を集中させることで選択的な 粉砕を促進させる。また，細粒化した粒子の排出を促す ことで過粉砕を防ぐこともでき，結果的に粗粒段階での 単体分離を達成させることができる。Fig. 3 の検討例は, 異なる銅品位の非実装プリント基板を用い，エアテーブ ル選別後の成績で, アクティブ粉砕と従来破砕機の単体 分離の度合いを比較したものである。銅品位 $59.4 \%$ の高 品位プリント基板を従来型ハンマクラッシャで破砕後, エアテーブルで選別した場合，銅の品位 $80.5 \%$, 総合分 離効率 $57.5 \%$ であった。一方, アクティブ粉砕を適用し た例では，同じェアテーブルで選別しても，銅品位 $35.0 \%$ の低品位プリント基板から，総合分離効率 73.6\% で銅品 位 $84.3 \%$ の産物を得ることに成功した。

しかし,アクティブ粉砕も, 必ずしも全ての廃製品の 単体分離促進に有効な訳ではない。今後, 個別の小型・ 
大木達也・古屋仲茂樹 - 西須佳宏・林 直人
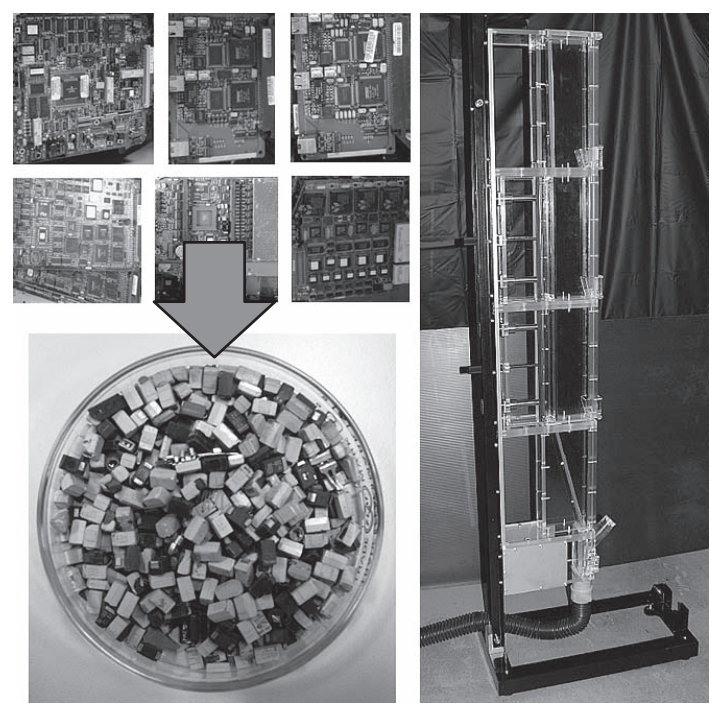

Fig. 4 Tantrum capacitors recovered with a pneumatic separator

中型家電製品等に対する実用的選択破砕機の選定, 改造, 開発へ展開することも予定している。

\section{2 総合選別システム}

選択粉砝により単体分離した粒子群が得られたとして も, この段階では, 未だ複数成分粒子の混合物であり, 着目成分を選別して回収しなければ意味がない。上述し た非実装プリント基板のように，銅とガラスーエポキシ 樹脂という単純な構成の場合には, 比較的容易に最適選 別条件を見出せることが多い。しかしながら，極めて多 くの種類の粒子から構成される場合, 特定の希少金属を 含む粒子だけを選別することは容易いことではない。こ の場合, 対象となる粒子群の情報をより正確に取得しな ければ，精密な分離をすることは困難である。

そこで, 筆者らはプリント基板に実装される電子素子 を対象に, 粒子群情報の調査を行った。プリント基板か ら剥離した 40 万個以上の電子素子について, 種類, 形 状, サイズ, 比重, 磁性等の物性データや, 篩分け, 磁 選, 気流選別等の選別データを取得した。そして, この 分析データに基づいて, 重量割合で $3 \%$ 程度しか含まれ ないタンタルコンデンサを, 回収率 $90 \%$, 品位（重量割 合） $90 \%$ 程度に濃縮できる選別条件を突き止めた。回収 されたタンタルコンデンサの例と選別プロセスの核とな る気流選別機（実験用試験機）を Fig. 4 亿示す。筆者ら が提案する気流選別を含む 3 段階の選別プロセスが取り 得た選別条件は約 4 兆通り存在したが, 先に取得した粒 子群情報の活用により, ごく短期間に最適選別条件を突 き止めることができだ1。

現在, 素子選別データベースに基づく自動選別制御が
可能な, 気流選別機のパイロット機を試作中である。ま た，筆者らが持つこの素子群の物性・選別データベース を利用し, 任意の電子素子の選別判定が可能なソフトウ エア「AIST 素子選別シミュレータ (仮称)」を開発中で ある。将来的にはこれらを応用し, 希少金属を含有する 製品や部品を自動的に認識しつつ, 自律的な選別制御が 可能な装置へと発展させる予定である。

\section{4. 物理選別技術の将来展望}

\section{1 技術開発の展開}

既述のように, 廃製品は粗粒段階で単体分離を達成さ せることが理想である。しかし，粉砕をすれば少なから ず細粒子が発生する。そして, 製品によっては希少金属 がこの細粒群に濃集する傾向を持つ場合もある。また, 電極材や製造工程の研磨屑など, その機能や発生要因か ら必然的に細粒子として回収されるものもある。多成分 が混在する成分分離, 特に $50 \mu \mathrm{m}$ 以下の粒子を対象とし た場合, 旧来は浮選に代表される表面性質利用の湿式選 別法しか選択肢がなかった。しかしながら, 1980 年以降, 強い遠心場を利用した比重選別機の開発が盛んになり, $10 \mu \mathrm{m}$ 程度の粒子までケミカルフリーの比重選別が適用 できる可能性が出てきている7,12。これらの新型比重選別 機は強力な遠心場で細粒子を速やかに選別できるが, 基 本的な選別原理は従来機と変わりなく, 選別精度が向上 しているわけではない。そこで，筆者らは未利用の作用 力であるコリオリの力を使った全く新しい原理の比重選 別・分級装置を開発中である ${ }^{13,14}$ 。コリオリセパレータと 名付けた本装置では, $10 \mu \mathrm{m}$ 以上の金属粒子に対して極 めてシャープな選別を, 多成分同時に達成することが可 能である。現在, さらに, シングルミクロン, サブミク ロンを対象とした選別装置についても開発中である。

このような選別装置を駆使した場合, 単に選別して特 定成分を濃縮するだけでなく, 特定サイズを有する粒子 だけを取り出すことで, 再生資源に付加価值を与えるこ とも可能である。また, 電球形蛍光ランプからの希土類 蛍光体の回収, 希土類泶光体を色別に選別したり ${ }^{15}$, 洗 浄により再利用する技術など, 細粒子に対する再利用, 再資源化技術についても, 研究を展開しているところで ある。

一方, 物理選別においてはこのよらな要素技術の開発 のみならず，膨大な選別パターンの組み合わせから最適 パターンをシステマティックに選出する技術も重要であ る。さらに, 選別プロセスの設備導入後も, 入荷した廃 製品に応じた操業条件の最適化も必要となる。筆者らで は, 将来の物理選別技術に必要な開発要素として「革新 的粉砕・選別装置開発」「最適選別プロセスの導入技術」 


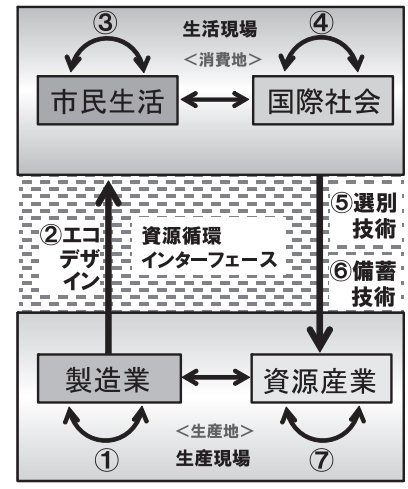

\section{生活現場の課題}

(社会的ルール作り)

\section{(2) (5) 6} 資源循環インターフェース
(資源䝠環を促進する潤滑剂)

\section{(1)(7)}

\section{生産現場の課題}

Fig. 5 Role of physical separation in the interface of resources recycling

「自動・自律的選別オペレーション」の 3 つ構築を重要 課題として掲げており，これらを柱にした技術開発の展 開を図ってゆく予定である。

\section{2 物理選別技術が担う役割}

金属資源の循環は，製品の製造，販売，消費，廃棄， 収集，原料化に至る一連の工程で滞りなく流通すること が重要となる。生産サイド，消費サイドの両者でリサイ クルが促されても，この両者が上手く橋渡しできなけれ ば，効率的な循環は実現しない。筆者らはそれを実現す る技術が選別技術，備蓄技術及び易リサイクル設計であ ろらと考えて扣り，この3つの技術を「資源循環インター フェース」と名付けた (Fig. 5 参照 $)^{8,16}$ 。

将来，理想的な物理選別技術が開発されたとしても， 製品の多様性から選別技術だけで全ての問題が解決する わけではない。どうしても効率的な選別ができない物に ついては, 製品段階から易リサイクル設計を盛り込むこ とで補ってもららしかない。この際，過度に易リサイク ル設計を取り込むことは，製品の価格や性能，利便性を 損ない，消費者の購入意欲の低下，延いては我が国工業 製品の国際競争力の低下に繋がりかねない。筆者らは, 易リサイクル設計に盛り込むべき必要最低限度の箇所 は，選別技術の限界とリンクさせることが合理的である と考えている。選別技術側からこれらの情報を提供する ことにより，易リサイクル設計の導入が強く期待される 箇所や思想を伝えることができ，製品本来の機能や魅力 を極力損ならことなしに，効果的なリサイクルの促進が なされると期待される。一方，易リサイクル設計が導入 され，また，選別技術を高度化しても，その時点では流 通性に乏しい，種々のグレードの中間産物が少なからず 発生する。有価か無価かといら現在のデジタルな評価で は,これらは臣とんど無価となってしまらかもしれない。 しかし，これらを再資源化可能な形で保管・備蓄して打 く制度や技術が確立されれば，その存在自体が生み出す
無形の価值を含め, 長期的に見れば我が国にとって重要 な資源となるに違いない。そして，この保管・備蓄すべ き金属の形態や発生量も，どのような中間産物が発生す るかといら，選別技術の発展に左右されることとなる。

このよらに, 物理選別技術は, 単にそれ自身の発展に よって希少金属リサイクルを促進させるだけでなく，易 リサイクル設計や備蓄技術導入の指針を示す，言わば資 源循環インターフェースの司令塔として機能することが 期待される。

\section{5. 結言}

希少金属リサイクルのための選別技術は，希少金属資 源循環の成否を左右する重要な技術として位置づけるこ とができる。その個別の技術開発はまだ始まったばかり であり，筆者らは，まずは，物理選別の技術的な可能性 を拡大寸るため，手選代替個別破砕・選別技術や集合破 砕・選別技術といった，要素技術開発を進めてゆきたい と考えている。一方，現状に扣いてその技術は，必ずし も系統的，組織的発展をするに至って抢らず，このこと が，選別技術の合理的導入や，資源循環インターフェー スの司令塔として，その機能が十分に発揮できないこと の要因となることが懸念される。このことから筆者らは, 要素技術開発のみならず，情報整理による技術の大系化 を進めることにより，物理選別技術の機能を最大化する ことで, 我が国に打ける希少金属資源循環の促進に貢献 してゆきたいと考えている。

\section{謝辞}

本稿で紹介した 3 次元レーザーセンシング技術は NEDO「マグネシウム鍛造部材技術開発プロジェクト」 （H18-H22），希土類蛍光体を色別に選別する技術は NEDO「高速合成，評価法による蛍光ランプ用蛍光体向 け $\mathrm{Tb}$ ，Eu低減技術」（H21-H23）にて開発したものであ る。タンタルコンデンサの選別プロセスは「廃小型電子・ 電気機器からの希少金属等の回収一粉砕基板の物理選 別」(H19-H22), 電球形蛍光ランプからの希土類蛍光体 の回収は「廃蛍光ランプからのテルビウム等希土類金属 抽出回收技術開発」（H21-H22）の各 JOGMEC との共同 研究により検討した技術である。また，アクティブ粉砕 ーエアテーブルによる基板からの銅濃縮技術は，韓国資 源地質研究院（KIGAM）との共同研究「Development of Total Recycling Technologies for Wasted Electric and Electronic Appliances」（H18-H21）によって，資源循環イン ターフェースの概念構築は，環境省廃棄物等科研費「循 環型社会ビジョン実現に向けた技術システムの評価モデ 
大木達也・古屋仲茂樹 ・西須佳宏・林 直人

ル構築と資源効率・環境効率の予測評価 (K2155)」(H20H22）にて検討したものである。また，当研究グループ の研究開発にご協力頂いた研究機関, 自治体, 民間企業 の皆様に対しまして，深く感謝の意を表します。

\section{References}

1. MOE and METI: Shiyouzumi kogatakaden karano raremetal kaisyu oyobi tekisei syori ni kansuru kenkyukai torimatome (2011)

2. S. Koyanaka and K. Kobayashi: RESOURCES, CONSERVATION \& RECYCLING, 55, pp. 515-523 (2011)

3. S. Koyanakla: Kankyo shigen kogakukai symposium 18th shiryousyu, pp. 19-26 (2009)

4. T. Oki: RARE EARTH, 56, pp. 198-199 (2010)

5. T. Oki, N. Wada, M. Matsumoto: RARE EARTH, 58, pp. 34-35 (2011)

6. T. Oki: Kinzoku, 81, 2, pp. 37-40 (2011)
7. T. Oki: Funtai Gijutsu, 1, 5, pp. 39-48 (2009)

8. T. Oki: Materia Japan, 50, 2, pp. 51-55 (2011)

9. S. Koyanaka, S. Endoh, H. Ohya: REVIEW OF AUTOMOTIVE ENGINEERING, 27, 2, pp. 353-355 (2006)

10. S. Koyanaka and K. Kobayashi: Resources Processing, 58, 1, pp. 22-27 (2011)

11. T. Oki, Y. Naito, T. Kamiya, K. Kawakita, T. Shiratori: Proceedings of IMPC 2010, pp. 3839-3844 (2010)

12. T. Oki: Kankyo shigen kogakukai symposium 16th shiryousyu, pp. 24-30 (2008)

13. T. Oki, T. Hazumi, Y. Umemiya: MMIJ Syunki Taikai Koensyu, pp. 171-172 (2009)

14. T. Oki, T. Hazumi, Y. Umemiya: MMIJ Syunki Taikai Koensyu, pp. 167-168 (2010)

15. T. Akai, M. Yamashita, T. Oki: RARE EARTH, 58, pp. 14-15 (2011)

16. T. Oki and N. Yamaguchi: Junkangata-Syakai Vision Jitsugen ni Muketa Gijutsu System no Hyoka Model Kochiku to Shigen-Koritsu·Kankyo-Koritsu no Yosoku Hyouka (K2155), pp. 122-152 (2010) 